\title{
3
}

\section{PREFIGURING ALTERNATIVES TO AUTOCRATIZATION}

\author{
Democratic dissent in contemporary India
}

\author{
Amrita Basu
}

A democracy that was once celebrated for its strong, autonomous institutions, vibrant civil society, and extensive civil rights and liberties, has sharply curtailed the peaceful expression of dissent. The Indian government has been censoring journalists and news outlets that criticize its repressive policies, disbanding progressive NGOs, and incarcerating critics without trial on baseless charges of sedition, defamation, and terrorism. Since assuming power in 2014, the Bharatiya Janata Party (BJP) government has decreed major policy changes, some of which violate federal and constitutional principles, with little deliberation and consultation. It has combined pro-poor populism and pro-corporate policies and promoted Hindu domination and minority subjugation. Two protests against these measures are especially significant: first, against the Citizenship Amendment Act (CAA) (2019-20), and second, against agrarian laws which render farmers more vulnerable to corporate exploitation (2020-present). An overview of the two protests will be followed by an exploration of how they challenge autocratization, through both their substantive demands and their democratic modes of organizing.

The most important of the many protests around the country opposing parliament's passage of the CAA occurred in Shaheen Bagh, southeast Delhi. On December 14, 2019, about a dozen women organized a sit-in at a highway, launching a 101-day nationwide movement; on some days it attracted 100,000 participants (Kumar and Abi-Habib 2020). The Shaheen Bagh protest persisted, despite record low temperatures, several court petitions seeking to evict the activists, and vicious rumours about them. The women vacated the protest site on March 24, 2020, when the government declared a lockdown to slow the spread of Covid-19.

The CAA provides an accelerated path to citizenship for non-Muslim immigrants who arrived in India before 2015 from neighbouring Muslim-majority countries. The Cabinet approved the creation of a National Population Register (NPR), which will document all Indian residents, citizens and non-citizens alike. The legislation empowers government functionaries to profile Muslims by requiring that they verify their citizenship. There is a clear link between the CAA and the government's publication of a version of the National Registry of Citizens (NRC) in Assam in August 2019, which excluded approximately two million people, including many Hindus who have lived in India for decades (BBC News 2019). The CAA enables Bengali Hindu migrants in Assam, whose names did not appear on the NRC, to 
become citizens. If the government pursues the implementation of the $\mathrm{NRC}$, as it has repeatedly stated it plans to do, it can revoke the citizenship of any Muslim who lacks documentation (Shankar 2020).

Several months after the anti-CAA protests, farmers organized a massive movement demanding that the government revoke three farm laws which eliminate guaranteed prices for certain crops and increase their vulnerability to corporate exploitation. The protests began in August, escalated in September, when parliament hurriedly passed the farm acts, and culminated on November 26th in a Dilli Chalo (Let's Go to Delhi) campaign; tens of thousands of farmers from Punjab and other north Indian states travelled to Delhi by foot, bicycle, and tractor to oppose what they called the black laws (Hollingsworth, Gupta, and Mitra 2020). The BJP-controlled Haryana government ordered police to dig trenches, create road blocks, and attack the farmers with water cannons, batons, tear gas, and rocks, to prevent them from entering the state. Undeterred, the farmers breached the barricades and blockaded roads, railway lines, and highways with tractors. They created makeshift camps at six entry points to Delhi; the largest were on the Singhu and Tikri borders. Carrying food, water, bedding, and other provisions that they claimed would last six months, they vowed to sit in until the government repealed the laws. Large numbers of women farmers joined the protest; 20,000-25,000 of them went to the Tikri border alone. By November 30, 2020, between 200,000 and 300,000 farmers had converged at border points on the way to Delhi (Mahajan 2020). To support the protesters, 250 million people across India - a global record - staged a 24-hour solidarity strike on November 26 (Pahwa 2020). Thousands of farmers entered the national capital on January 25 in anticipation of Republic Day celebrations and organized processions on government approved routes. Some protesters broke away, destroyed property, and injured hundreds of police officers. Movement leaders condemned this violence, which they believe was perpetrated by government supporters, and persuaded the farmers to return to the border sites. Relations between the government and the farmers' movement have become increasingly fraught. The government removed protesters' songs from YouTube, blocked their internet access, brought charges of sedition against journalists who have been covering the events, condemned international activists and celebrities who have supported the protests, and erected iron spikes on the entry points to Delhi. Mahapanchayats (congregations of village councils) in Haryana and Uttar Pradesh have organized huge gatherings to support the farmers' demands and condemn the government's actions. Participation in the sit-ins at the border sites subsequently grew. As of March 21, 2021, around 40,000 people were camping out at Singhu and Tikri.

Public investment in agriculture has long been declining, farmers' incomes and returns on investments have been falling, and indebtedness has been increasing (Ghosh 2020). North Indian farmers feel betrayed by Prime Minister Modi, who they voted for in the 2014 elections, because he promised to double their incomes in five years by increasing minimum support prices for agricultural produce. Instead, procurement prices under the current regime have been even lower relative to their costs than under the previous government (Himanshu 2019). Although the government claims that the reforms will free farmers from traditional wholesale mandis (markets), farmers allege that they will eliminate the safety net that minimum support prices provide. They oppose the weakening of regulated markets and public procurement and the vesting of authority to settle disputes in the central government and the bureaucracy rather than state governments and local panchayats. They also fear that private corporations, both domestic and global, will be able to determine what crops they grow and what prices they charge - which will increase landlessness, pauperization, and indebtedness.

The Shaheen Bagh and the farmers' protests have overcome the hurdles that single issue, grass roots movements typically encounter. Whereas distinctive cultural and political conditions 
confine most protests to the localities where they emerge, both of these broad-based national movements inspired similar protests in numerous places in Delhi and around the country. Those who could not visit or remain in Shaheen Bagh staged sit-ins wherever they lived. In one of our interviews ${ }^{1}$, Ziya Us Salam, journalist and author, quoted a popular slogan, "every city, Shaheen Bagh". Punjabi Sikh farmers have been at the forefront of the protests because of the strength of their agricultural unions, their vital contributions to national food production, and their anger at the government's attempts to discredit them. ${ }^{2}$ Many cities created their own "Nation for Farmers" campaigns. Protests in support of the farmers' movement have taken place across the world.

Notwithstanding several similarities between the two movements, the farmers' movement is larger and organizationally stronger. It is the culmination of a long history of mobilization by agrarian unions in Punjab and other states. Whereas the Shaheen Bagh movement lacked resources and organizational infrastructure, 40 farmers' unions created the Samyukta Kisan Morcha (Joint Farmers Front) to coordinate their efforts in November 2020. Compared to Shaheen Bagh, the farmers' movement enjoyed greater support from political parties, women's organizations, trade unions, and philanthropic groups. This is probably the result of several factors, including greater anti-Muslim than anti-Sikh sentiment. Farmers constitute a large voting bloc. Because 70 percent of the population derives its livelihood primarily from agriculture, farmers are considered indispensable to national wellbeing. For all of these reasons, the government was willing to negotiate with the famers, but not with the Shaheen Bagh protesters. However, the size and scale of the farmers' movement is both an asset and the source of potential internal division. For example, although Rakesh Tikait, a leader of the largest farmers' union, the Bharatiya Kisan Union (BKU), from Uttar Pradesh, had mobilized tens of thousands of people to participate in the farmers' protest since January 26, many activists distrust him because of his role in anti-Muslim violence in Muzaffarnagar in 2013.

Both movements challenged autocratization in four important ways, each of which will be analyzed in turn in this chapter. First, the Muslims who took the lead in anti-CAA protests and Punjabi Sikhs who spearheaded the farmers' protest, refuted allegations that as religious minorities, they were anti-national, and proudly affirmed both their faith and their secular commitments.

A second way that activists challenged autocratization, and in particular, the regime's hierarchical, secretive character, was by forging egalitarian, inclusive, communities. I describe this orientation as prefigurative, in that activists demonstrate through deliberative, inclusive processes, a commitment to democratic means and ends. The Shaheen Bagh and farmers' movements share the prefigurative orientations of many pro-democracy, anti-authoritarian movements that have emerged over the past decade in other parts of the world. Examples include feminist, square occupation, anti-globalization, and environmental movements (Berman 2019, Leach 2013, Yates 2020). Like prefigurative movements and orientations in other contexts, these two movements are moral, cultural, and expressive (Epstein 1991) and challenge dominant cultural codes (Melucci 1996). Although scholars tend to depict prefigurative as opposed to instrumentalist or strategic approaches as reflecting different priorities and world views (see Gorz 1968 and Boggs 1977), the two orientations need not be mutually exclusive. To the extent they diverge, this is related to differences in the movements' class, ethnic, and gender compositions, which influence in turn the resources they command.

Third, women in both movements challenged the government's populist claims to represent and protect them. Muslim women from Shaheen Bagh occupied public space and defied the narrow boundaries of identity politics to which Hindu nationalists have consigned them. 
Women farmers spoke out against being rendered invisible by landlessness and the lack of social recognition of their labour (Quint 2020b).

Fourth, if the movements' democratic modes of activism challenge autocratization, so do their demands. Both movements have shown that the laws they oppose do not simply concern particular groups and issues but are relevant to all citizens because they erode democratic principles and privilege corporate over people's interests.

\section{Linking secular and religious ideals}

The BJP government conflates the Hindu majority with the "common people," while vilifying some religious minorities and seeking to assimilate others. On the one hand, it has sought to discredit and intimidate Muslims in Shaheen Bagh and Sikh farmers by describing Muslims as Pakistani terrorists and Sikhs as Khalistani separatists (in reference to the Sikh separatist movement in Punjab). Popular conspiracy theories claimed that the protesting farmers were actually Muslims, not Sikhs, and that Bilkis Bano, a renowned Shaheen Bagh activist, was paid to join the farmers' movement. (In fact, the police prevented Bilkis Bano from joining the sit-in.) (Jagga 2021, Pandey 2020). On the other hand, the government and right-wing social media have engaged in greater demonization of Muslims than of Sikhs. Hindu nationalists claim that Muslims are outsiders, whereas Sikhism is part of Hinduism. For example, on Gurpurab in November 2020, one of the holiest Sikh holidays and the birth anniversary of Guru Nanak, the founder of Sikhism, Prime Minister Modi tweeted, "I bow to Sri Guru Nanak Dev Ji on his Parkash Purab. May his thoughts keep motivating us to serve society and ensure a better planet"(Modi 2020).

Both protests have resisted the government's attempts to use religion to discredit and divide them. In opposing the CAA, Shaheen Bagh activists highlighted Muslims' daily experience of fear because of their clothing, names, and other markers of identity. In response to Modi's statement that you can identify those who engage in violence "by their clothes" (Quint 2019), women in burqas at Shaheen Bagh linked their faith to their democratic commitments. Ziya us Salam told us that many women felt that demanding constitutional rights was the will of Allah who believed, " ...to fight for justice is the calling of every human being". As Hilal Ahmed (2020) argues, the protesters showed that far from turning them inward, their religious beliefs were tethered to their nationalist commitments.

The Shaheen Bagh protesters drew on early understandings of Indian secularism that promoted equality among people of all religions. They recited scriptures from the Gita, the Bible, the Quran, and the Guru Grant Sahib (Week 2020), as well as revolutionary poems by Pash, Habib Jalib, Muhammad Iqbal, and Ramdhari Singh Dinkar (PTI 2020). Challenging the BJP's allegations of their sectarianism, they demonstrated their support for another displaced group by organizing a meeting on January 19, 2020 in support of pandits (Brahmin Hindus) who were forced by militant groups to leave Kashmir in the 1990s (Ashraf 2020).

Sikh farmers resisted the government's misappropriation of their religion by organizing their own celebration of Gurpurab on the Singhu border where they prayed to Guru Nanak to make the government revoke the black laws (Hindustan Times 2020). Farmers at the sit-ins quote scriptures like 'sarbat da bhalla' (welfare for all) and invoke kar seva (selfless service) to affirm Sikhs' commitment to the dignity of labour and opposition to the caste system. The camps on the border sites embody Sikh principles of sewa (service) and langar (a community kitchen in Sikh temples which serves free meals to all visitors, regardless of their religion, caste, class, and gender).

Sikhs also contest the government's attempt to discredit them as terrorists and Khalistani separatists (Arora 2020). One of their posters wryly proclaims, "When we save Hindus, we are 
angels; when we die to save the nation, we are martyrs; when we fight for our rights, we are Khalistani." They invoke memories of Punjabi revolutionaries and chant "Inquilab Zindabad" (Long Live Revolution). Posters of the young Sikh anti-colonial nationalist, Bhagat Singh, adorn the protest sites; young men wear tee shirts bearing his image, and women wear yellow scarves, the colour of his turban. Repudiating what they term the "godi" (lapdog or compliant) media, the farmers' movement has created its own YouTube channel, the Kisan Ekta Morcha, and the bi-weekly Trolley Times newspaper. According to Harinder Kaur Bindu, a leader of the BKU-Ekta Ugrahan, who we interviewed, the government's attempts to discredit the movement have backfired and revealed its own sectarianism.

Remarkable expressions of solidarity among opponents of the CAA and the farm laws attest to some of their shared experiences as religious minorities. The BKU organized a large delegation of Sikh farmers to travel from Malerkotla Punjab to join the protesters in Shaheen Bagh, in December 2019. The farmers brought posters which said in Urdu, "May brothers never fight again, may 1947 never be repeated" (Prabhu 2020). Recalling the horrific violence of Partition, but the ability of Sikhs and Muslims to prevent it in Malerkotla, they called for renewed unity in the face of the government's attempts to divide them (Rawat and Sanyal 2020). Sikh farmers brought rations and equipment to provide free meals to the surrounding community. A Delhibased Sikh advocate, DS Bindra, reportedly sold a flat to set up a langar at Shaheen Bagh and other protest sites. As a result, he has been harassed by right-wing social media and the Delhi police (A. Menon 2020).

Muslims from Malerkotla reciprocated by travelling to the farmers' encampments at the Singhu border and preparing meals for them. Many women at the farmers' sit-ins said they were inspired by Shaheen Bagh women. Amandeep Kaur Deol of the Stree Jagriti Ekta Manch, who we interviewed, said that participating in anti-CAA protests gave her the confidence to become active in the farmers' movement. "We began to see that if women in Shaheen Bagh did not take the permission of their husbands, why should we?"

Both movements challenge autocratization by dispelling false characterizations of Islam and Sikhism, highlighting the way both religions promote equality, tolerance, and justice, and forging solidarities based on shared histories and aspirations.

\section{Prefigurative movements}

A hallmark of a prefigurative orientation is the creation of expressive, non-instrumental modes of communication. Both the Shaheen Bagh and the farmers' sit-ins became the sites of posters, murals, and art displays, that creatively challenged official narratives They were also the site of musical performances which forged composite cultural identities by drawing on diverse linguistic, regional, and religious traditions. The songs keep alive memories of resistance to repression in other times and places. The most popular songs at Shaheen Bagh included Aamir Aziz's Sab Yaad Rakha Jayega (We will remember everything, we will remember it all) and Faiz Ahmad Faiz's poem 'Hum Dekhenge', which was popularized in Lahore in 1986 to protest martial law in Pakistan under Zia-ul-Haq (Singh 2019) and was translated amidst the sit-in from Urdu into numerous regional languages.

Some 650 songs that the farmers' movement generated are inspired by rap, Sikh hymns, and folk melodies from Punjab and Haryana. They express the festivity associated with weddings, the faith evoked by religious hymns, and the revolutionary zeal associated with radical traditions. The songs of the Dalit poet Sant Ram Udasi (1939-1986) have become extremely popular.

Another hallmark of a prefigurative orientation is that it fuses a commitment to transforming both civil and political society. Contrary to Partha Chatterjee's view that there is a split in 
post-colonial societies between civil society, which is characterized by elitist, statist values, and political society, which is the realm of subaltern politics (Chatterjee 2004), both movements demand accountability from the state and civic responsibility for community welfare (food, housing, and shelter). People of different backgrounds and identities share responsibilities for cleaning, cooking, and childcare. The sites include health centres where doctors prescribe medications and health examinations. The camps the farmers have created on the border sites have gyms, salons, blood donation clinics, and libraries. Volunteers distribute refreshments and meals throughout the day to visitors and poor people from the neighbourhood.

The citizenship rights Shaheen Bagh women demanded were intimate and emotive. Intimate citizenship, Kenneth Plummer writes, does not "imply one voice, one way, or one model". On the contrary, it "...designates an array of stories and a multiplicity of voices, in which different lives, different communities, and different politics dwell” (Plummer 2003). Shaheen Bagh attracted people from a wide range of backgrounds and political affiliations. Strong bonds developed between older local residents and students from the neighbouring Jamia Milia Islamia University (hereafter Jamia). Punjabi farmers who joined the protest raised awareness about public policies that have contributed to the agrarian crisis. Trans activists joined the protest to oppose both the CAA and the new Transgender Persons (Protection of Rights) Bill, 2019, which requires proof of gender confirmation surgery for someone to be registered as transgender (Sarfaraz 2020). Even some BJP supporters, like Saksham Mishra from Kanpur, joined the protest because the new laws were, in Mishra's words, an "assault on the cultural fabric of the nation" (Mishra 2020).

The protesters at Shaheen Bagh promoted inclusive, pluralist citizenship. They exuberantly affirmed inclusive nationalism by reciting the national anthem at midnight on New Year's Eve, hoisting the tricolour on Republic Day, and inviting Modi to celebrate the festival of love on Valentine's Day. They distributed rose petals to the police. The most often read book at the site was the Constitution. Protesters read it aloud and displayed posters of its author, Dalit leader B. R. Ambedkar.

Compared to the Shaheen Bagh protest, the farmers' movement was less inclusive of the most vulnerable groups. The farmers' unions, which initially organized the protest, are dominated by Jat landowners in Punjab. They have not addressed questions that most concern landless labourers, like the recent passage of labour laws which extend the working day and dismantle workers' protections. Nonetheless, in early January, organizations of Dalit labourers, like the Punjab Khet Mazdoor Union and agricultural unions from Rajasthan and Maharashtra, which are more representative of landless and low caste labourers, refuted the government's charge that farmers were simply seeking to protect their class interests, and joined the sit-in at Tikri (Singh 2021). By participating, they reject the government's claims to champion Dalit rights, thereby demonstrating their opposition to autocratization. The Samyukta Kisan Morcha has welcomed their participation and called for broad class unity. Sikh gurdwaras (temples), which provide enormous support to the farmers' movement, emphasize equality across caste and class lines.

Prefigurative movements generally favour grass roots mobilization over electoral orientations. In this respect the two movements are similar. To maintain the movement's autonomy, the farmers' movement has not included even supportive party leaders in the negotiations with the government or allowed officials to speak on their platforms. To promote transparency and prevent dependence on any one leader, representatives from 31 farmers' unions alternate participating in these negotiations. Gurmeet Singh, vice-president of the BKU-Ekta Ugrahan, commented (Sethi 2020), 
The pradhan (head) of the day chairs the meeting and later addresses the press about the decisions. No union leader should feel that because he is heading a smaller union he does not have the same say as the head of a larger union... This also makes it difficult for anyone to break the unity because in this kind of leadership everybody matters.

A comparison between the two movements suggests that a prefigurative orientation is born of both choice and necessity. The Shaheen Bagh movement defied instrumental logic in continuing the sit-in, despite the government's refusal to consider its demands, and prefigured democracy by enacting inclusive citizenship. The farmers' sit-ins were necessitated by the government's refusal to allow protesters into Delhi. However, despite growing public support and the government's increased willingness to negotiate, the movement refused to compromise. While engaging in a prefigurative approach, the farmers strategized, coordinated, mobilized, forged coalitions, marshalled resources, and determined how to frame their demands. The prefigurative orientation of both movements represented important challenges to autocratization.

\section{Women's activism}

Women in Shaheen Bagh and the farmers' protests have highlighted the detrimental impact of government laws and policies on their individual and societal roles. The government claims to promote women's empowerment and honour women's roles as wives and mothers while pursuing policies which undermine women's rights and the wellbeing of their families and communities. It paternalistically speaks for and about women while rendering them invisible as workers and citizens. Women in both movements have claimed voice and visibility as individuals, wives, mothers, and widows, thereby demonstrating their conjoined commitments to their communities and to their interests as victims of gender inequality.

In sharp contrast to the state's confrontational, aggressive, masculinist stance, the Shaheen Bagh sit-in reflected typically female values of nurturance, patience, and perseverance. Three local elderly women who are known as the Shaheen Bagh dadis (grandmothers) represent maternal strength, fortitude, and compassion. Nicholas Gill argues that those who experience temporary and shifting citizenship tend to value stillness in resisting exclusion (Gill 2009). The act of waiting patiently also offers a sharp contrast to the government's hurried and secretive decision-making style. Having experienced frequent displacement both before and after Partition, women resisted by refusing to be uprooted from their homes and communities. As Lucy Jackson (2016) theorizes, groups excluded from state-defined citizenry attach strong affective value to citizenship. They experience what she terms "emotive citizenship", that is "situated within their everyday intimate lives", and rooted in the here and now of home.

By anchoring motherhood within democratic values, Muslim women engage in what Werbner terms "political motherhood" (Werbner 1999, 221). They have opposed police violence against their husbands, sons, and grandsons who the state frames as anti-national terrorists and sexual predators. The catalyst to the Shaheen Bagh women's sit-in was their outrage at police attacks on students who were peacefully protesting against the CAA at Jamia. A video clip that went viral depicts four women surrounding a male student at Jamia to protect him from the police (Kuchay 2019). The protesters challenged Modi's claims to empower women through programmes like 'Beti Bachao, Beti Padhao' (Save the Daughter, Educate the Daughter), while disregarding the sufferings of women and girls who were sitting in the cold on the streets (NDTV 2020). 
Several poems and songs challenge masculinist logic with symbols of feminine strength. Nabiya Khan's poem, that went viral, begins, "the revolution will come wearing bangles, bindis and hijabs". Darab Farooqui's poem, The Name is Shaheen Bagh, reflects the ways feminine modalities of protest imbue the movement with the warmth, love, and support that is commonly associated with home and community (Quint 2020a). A poster at Shaheen Bagh says: "Women's slogans will herald the uprising." A frequently heard refrain, drawn from South Asian women's movements, concerns azaadi (freedom). Its opening lines are: "My sisters demand freedom, freedom is our right, we will claim freedom, come what may." Azaadi, of course, refers to freedom from both patriarchal and state oppression (Menon 2020).

The Shaheen Bagh protest fostered what Farida Ayub called bedari (an awakening) about women's public roles. She told us: "People have understood that when women raise their voices, they strengthen communities and elevate them to new heights." Maya Bhagat said, "Men have always treated women as objects, as people who have to be told what to do. They think women can't have independent minds. This stereotype is so inbuilt that now we can't believe that women are standing up." Zaara Hashmi told us in an interview:

People began to understand and listen to us. When we're in our homes, we can't be heard, but on the streets we can. Women were already aware, that is why they came out to protest. The movement made society realize that a woman's purpose is not just to have children and cook food. We can do a lot for this nation. We have capabilities that are suppressed, and (the protests) have created an atmosphere in which every woman can realize her potential.

Women have also played leading roles in the farmers' protests. More than 40,000 women joined the BKU-Ekta Ugrahan, and thousands of women joined 30 other farmers' unions in Punjab. The agrarian crisis has magnified gender inequalities and politicized women. The burdens on women have increased as a result of male migration to the cities rendering women increasingly responsible for what was traditionally considered men's work. Most of the women who joined Dilli Chalo were from the Malwa region, which has witnessed the highest rate of farmers' suicides in Punjab. Because more male than female farmers commit suicide as a result of indebtedness, the burdens of repaying debts at exorbitant interest rates fall largely on widows, who own little or no land. According to Kavitha Kuruganti of the All India Kisan Sangharsh Coordination Committee, although women conduct 75 percent of all farm work, they own only 12 percent of the land. She notes that the new laws will increase women's susceptibility to exploitation and make their labour even more invisible (Shergill 2020). Amandeep Kaur Deol commented in an interview, "As it is, we don't own land in our names and are paid half of what men earn. Unemployment is already so high. If we're forced to migrate to the cities, the only work we'll find will be as sex workers."

Fewer women have achieved leadership roles in the farmers' movement than in the Shaheen Bagh protests. Whereas Shaheen Bagh women organized within their own localities, female farmers must suspend their responsibilities to their families and cultivation and travel long distances to join the farmers' sit-ins. They have devised a partial solution by developing a rotation system whereby some women periodically return to their homes and other women from their villages replace them at the sit-in. Furthermore, some of the male leaders of the movement initially viewed women with suspicion and questioned why they were there (Kaur 2020). These women confronted the male leaders and persuaded them to allow more women to speak.

Farming women have been increasingly politicized over the course of the sit-in. They organized protests across the country to celebrate "Women Farmers Day" on January 18, 2021. 
They were outraged when the Supreme Court Chief Justice SA Bobde urged women and the elderly to return home and implied that they were being "kept" at the protest (Newsclick 2021). Kavitha Kurungati commented, "One of the important points of concern is the paternalism and patriarchy reflected in observations with regard to women farmers. We urge the respected institution of the Supreme Court to recognise and appreciate the agency of women in this matter" (Bajwa 2021). Harinder Kaur Bindu who we interviewed travelled to the Tikri border on November 26 and has returned there intermittently. She said, "This was the firsttime women travelled such long distances, often 300-400 kilometres. When there was no one to take care of our children and elderly relatives with us, we took them along. Men have come to realize that we have to join the movement for it to succeed." Men at the sit-ins have gained more respect for women's activism; they have signalled that sexual harassment will not be tolerated. Several women at the Tikri border commented that men did not assume that cooking and cleaning was primarily women's work.

Through their occupation of public space and their public voice and visibility, women in both movements have simultaneously challenged repressive laws and demanded an expanding bundle of citizenship rights.

\section{Challenges to neoliberalism and democratic erosion}

Through their opposition to particular laws, both the Shaheen Bagh and farmers' movement engage in a broader critique of autocratization. Those who are excluded from citizenship rights are often at the forefront of struggles to achieve them. The Shaheen Bagh protesters are mindful, as Giorgio Agamben (2017) argues, that citizenship as a marker of political belonging supersedes social belonging in the nation-state. Agamben theorizes that the state's inclusion of citizens is premised on the exclusion of the non-citizen (what he calls bare life). For Agamben, the exclusion of non-citizens or stateless people ironically creates the foundations of citizenship.

For the Shaheen Bagh activists, demands for citizenship became a fulcrum for addressing a multitude of societal problems and state policies, including the threat of violent displacement, discrimination against Muslims, gender inequality, unemployment, poverty, and the lack of civic amenities in poor neighbourhoods. Amira Bashir told us that protesters criticized the government for investing millions of rupees in the NPR and NRC rather than funding programmes for women and the poor: "There is no budget for tabdeeli (progress or change), so poor people will suffer... The government should use funds to support migrant workers, and rape and child abuse victims. They should improve rural healthcare; even today poor people are dying because there are no doctors in their villages."

The Shaheen Bagh protesters show that, far from being empty abstractions, citizenship rights are crucial to the security and wellbeing of low income, marginalized communities. Their Citizens' Charter states: "Our struggle has been for an inclusive and participatory form of citizenship based on values of mutual empathy, care, and dignity. Now that we are called upon to show our commitment to these values, we shall rise to the occasion" (India Legal 2020). It emphasizes that "enshrined alongside their right to life and citizenship, is the inalienable right to a life of dignity, and these seemingly smaller issues are also an indicator of how (they) are treated as lesser citizens" (Shaheen Bagh Official 2020).

The pandemic has widened the chasm between the rich and poor and revealed the tensions between the government's populist and neoliberal policies. The farmers' unions have challenged three key features of autocratization: the growing centralization of power, the state's capitulation to business elites, and the violation of civil rights and liberties. In challenging the government's call for "One India, One Agriculture Market”, farmers' unions uphold constitutional and federal 
principles that identify agriculture as the responsibility of state governments. This shows that the growing centralization of power undermines regional and local decision-making processes, while increasing corporate control (Singh 2020).

The farmers' movement claims that the state is catering to the interests of two of India's wealthiest families, Mukesh Ambani, the chair and managing director of Reliance Industries, and Gautam Adnani, chair of the Adnani multinational conglomerate. General secretary of the BKU-Ekta Dakaunda, Jagmohan Singh Patiala, commented, "We believe the newly enacted farm laws were passed to facilitate Reliance's entry into the farm sector. This is the only business which will never incur loss as everyone needs food, fruits, and vegetables" (Vishwadeepak 2020).

Union activists have called for the boycott of Reliance and Adnani products through social media, slogans, speeches, posters, and bumper stickers. Farmers have been switching their phone service from the Reliance-owned Jio to other mobile phone providers. In small towns and villages in Punjab, people have engaged in violent attacks on Reliance property. They have burned Reliance Jio SIM cards, destroyed cell phone towers, forced Adani's silos to close, disconnected power supplies to Jio mobile towers, and taken control of Reliance stores, petrol pumps, and a toll plaza (Bellman 2020). Leaders of the farmers' movement have supported the boycott but called for peaceful protest.

The farmers' unions have compared the government's high-handed passage of the farm laws with its decisions to demonetize currency in 2016 and abrogate Kashmir's special status in 2019. They charge that the government timed the passage of the farm laws amidst the pandemic lockdown to prevent protest. They have refused to co-operate with the committee the Supreme Court appointed to resolve the dispute because its four members have been vocal advocates of the farm laws. They have demanded that the government convene a special session of parliament where the farm laws can be openly reviewed.

Activists point out that one frequently ignored aspect of the reform is that it denies citizens legal recourse to dispute government actions. Section 13 of The Farmers' Produce Trade and Commerce (Promotion and Facilitation) Act, 2020, better known as the APMC Bypass Act, states that no legal proceedings, prosecutions or lawsuits can be brought against the central or state governments or their officers with "respect of anything which is in good faith done or intended to be done under this Act or of any rules or orders made thereunder". This provision prevents any citizen from pursuing public interest litigation against the government and big business (Sainath 2020).

The farmers' movement has taken a strong stand on the regime's violation of civil rights and liberties. On Human Rights Day, December 10, 2020, photographs of people who the government had incarcerated, adorned the podium on the Tikri border. The BKU Ekta-Ugrahan condemned the government for using draconian laws to imprison intellectuals, artists, activists, and anyone accused of challenging the regime. It released a statement which said, "The state wants people to remain confined to their narrow identities and narrow interests so that no one resists people being subjected to repression and torture." By demanding the release of political prisoners, the farmers' movement identified itself with a broader "people's struggle" (Brar 2020). In taking this stance, the farmers' movement not only opposed the incarceration of its own members but of everyone who challenges autocratization.

\section{Conclusion}

Judged solely by their political effectiveness, prefigurative movements have had mixed results. The Arab Spring generated hopes for democracy which were dashed by repression, coups, and 
civil wars. However, sit-ins must also be evaluated relative to alternative possibilities. Under prevailing political conditions, opportunities for expressing dissent are relatively limited; institutional channels are blocked and national political parties lack courage, power, and imagination. Although the activists at the sit-ins faced threats and harassment, their reliance on collective leadership and their sheer numbers, provided some protection from police violence and mass arrests. Unlike single acts of protest which by definition are of relatively short duration, prolonged sit-ins provide continual public reminders of popular discontent.

Regardless of their outcomes, prolonged-sits are often democratic acts. They educate the public about the dangers of government overreach and demonstrate the importance of active citizenship. They redefine who is a legitimate political actor and what is a legitimate form of political participation. They enable women to increase public awareness of the invisible labour they perform and to transgress the public-private divide (Sasson-Levy and Rapoport 2003, 399). As Asef Bayat notes, urban street occupations symbolically transcend "the physicality of the street, to convey collective sentiments of a nation or a community" (Bayat 2010, 212). Even when they fail to achieve their goals, they foster activism among other groups. The farmers' movement followed nation-wide protest against discriminatory citizenship laws. Other movements will surely follow.

The protests challenge the Indian state's attribution of political discontent to disaffected political elites who want to divide the country (the so-called "tukde-tukde gang). The sitins are not only the work of a broad swathe of society but their demands affirm broad-based nationalism and citizenship rights. People at Shaheen Bagh wore images of the flags on their bodies and continually read and posted passages from the Constitution. Punjabis expressed pride at serving in the army and feeding the nation. Popular slogans at the farmers' protest sites included "Hail the nation, Hail the farmer", and "No farmers, no food". Supporters of the protest refer to the farmers as India's "food soldiers". In reciting prayers as well as revolutionary slogans, both movements demonstrated the potential complementarity of faith, tolerance, and secularism. In cooking and eating together, participants rejected the caste and gender hierarchies that dietary practices create and sustain. In feeding police officers and the poor in neighbouring locales, they repudiated the discriminatory and opportunistic bases on which Hindu nationalists provide social services. Mothers and grandmothers showed that far from confining them to their homes, their domestic work and invisible labour fuelled their opposition to gender inequality.

In describing the historical memories that inspire occupations of public squares, Atef Said writes, "Spaces carry meanings that are constructed over time, redeployed and reconfigured in the present, and carried forward as inspiration for the future" (Said 2015). Both movements linked their attachment to the land to their identities, histories, and imagined futures. Older people shared stories about partition and anti-colonial nationalism while younger people described their experiences in students' and women's movements. Activists said that as important as their immediate goals were their legacies for future generations. Zaara Hashmi commented in an interview about Shaheen Bagh: "When our children ask us, 'where were you all when this was happening?' we can say, 'we were sitting on the streets fighting for you.' In this, we were successful: that we can look the next generation in the eye without shame and know that with whatever life we had in us, we fought." Amandeep Kaur asked, "What can we leave behind for our children other than a record of our struggle?"

Both the Shaheen Bagh and farmers' sit-ins draw on past memories to overcome fear and express hope for a more just future. By so doing they prefigure democratic alternatives to autocratization. 


\section{Notes}

1 In addition to my own observations when I visited Shaheen Bagh in December 2019, Barkha Bhandari interviewed several students, activists, and journalists, in August 2020. And Ghazala Khan interviewed members of the farmer's union, women's organizations, and other activists in Malerkotla, Punjab in July-August 2020 and in February 2021. I use pseudonyms for many of the people who were interviewed. I'm grateful to Joan Cocks, Cynthia Enloe, Jayati Ghosh, Dipankar Gupta, Zoya Hasan, Mary Katzenstein, Mark Kesselman, Amna Pathan, Pritam Singh, Sten Widmalm, and Elisabeth Wood, for very helpful comments on this chapter.

2 For complex reasons that are beyond the scope of this chapter, farmers' unions in other parts of the country have had mixed responses to the protests; Maharashtrian unions have opposed it whereas unions in southern states have joined the sit-ins.

\section{Bibliography}

Agamben, Giorgio. 2017. The Omnibus: Homo Sacer. Redwood City, CA: Stanford University Press.

Ahmed, Hilal. 2020. "Who Represents India's Muslims? Thanks to CAA Protests, We now Know the Answer." Print, January 17, 2020. https://theprint.in/opinion/who-represents-indias-muslims-thanksto-caa-protests-we-now-know-the-answer/350709/.

Arora, Kusum. 2020. "Farmers' Protest: Despite Rightwing Propaganda, 'Khalistani' Angle Finds Little Traction." The Wire, December 2, 2020. https://thewire.in/agriculture/farmers-protest-despiterightwing-propaganda-khalistani-angle-finds-little-traction.

Ashraf, Asad. 2020. "Shaheen Bagh Protesters Express Solidarity with Kashmiri Pandits on Exodus Day." India Today, January 20, 2020. www.indiatoday.in/india/story/kashmiri-pandits-exodusdaymigration-refugees-1638294-2020-01-19.

BBC News. 2019. "India Puts 1.9m People at Risk of Statelessness." August 31, 2019. www.bbc.com/ news/world-asia-india-49520593.

Bajwa, Harpreet. 2021. "Farmers to Sit for Ninth Round of talks on Friday; Unions say Don't Have Much Expectations for Modi Government." Indian Express, January 15, 2021, www.newindianexpress.com/ nation/2021/jan/15/farmers-to-sit-for-ninth-round-of-talks-on-friday-unions-say-dont-have-muchexpectations-from-modi-government-2250367.html.

Bayat, Asef. 2010. Life as Politics: How Ordinary People Change the Middle East. Redwood City, CA: Stanford University Press.

Bellman, Eric 2020. "Protesting Farmers Target India's Largest Cell Company and its Billionaire Owner; More than 2,000 Cell Towers Operated by Mukesh Ambani's Reliance Industries have been Damaged Amid a Backlash Over Agriculture Deregulation.” Wall Street Journal (Online), January 6, 2021, Pro Quest. Web. January 10, 2021.

Berman, Sheri. 2019. Democracy and Dictatorship in Europe: from the Ancien Régime to the Present Day. New York: Oxford University Press.

Boggs, Carl. 1977. "Revolutionary Process, Political Strategy, and the Dilemma of Power." Theory \& Society, 4(3): 359 .

Brar, Kamaldeep Singh. 2020. "BKU (Ugrahan) to Seek Release of 'Rights Activists', Delhi Riots Accused." Indian Express, December 10, 2020. https://indianexpress.com/article/india/bku-ugrahanto-seek-release-of-rights-activists-delhi-riots-accused-7098812/.

Chatterjee, Partha. 2004. The Politics of the Governed. New York: Columbia University Press.

Epstein, Barbara 1991. Political Protest and Cultural Revolution: Nonviolent Direct Action in the 1970s and 1980s. Berkeley: University of California Press.

Ghosh, Jayati. 2020. "A Critique of the Indian Government's Response to the COVID-19 Pandemic." Economia e Politica Industriale: Journal of Industrial and Business Economics, 47(3-12), 519-530.

Gill, Nicholas. 2009. "Longing for Stillness: The Forced Movement of Asylum Seekers.' M/C Journal, 12(1).

Gorz, Andre. 1968. “The Way Forward.” New Left Review, I, 47-66.

Himanshu. 2019. "What Happened to Poverty during the First Term of Modi?" Mint, August 15, 2019.

Hindustan Times. 2020. "Farmers Protesting at Delhi Border Offer Prayers on Guru Nanak Jayanti, Distribute 'Prasad'." November 30, 2020. www.hindustantimes.com/india-news/farmers-protesting-at-delhiborder-offer-prayers-on-guru-nanak-jayanti-distribute-prasad/story-guym76JB9Me7Wk3qN9pd8. 


\section{Democratic dissent in contemporary India}

Hollingsworth, Julia, Swati Gupta, and Esha Mitra. 2020. “Tens of Thousands of Farmers Swarm India's Capital to Protest Deregulation Rules." CNN, December 6, 2020. www.cnn.com/2020/12/01/asia/ delhi-farmers-india-protests-intl-hnk/index.html.

India Legal. 2020. "A Letter Addressed to the Judges of Supreme Court by 'the People of Shaheen Bagh'." March 26, 2020. www.indialegallive.com/top-news-of-the-day/news/letter-addressed-judgessupreme-court-people-shaheen-bagh/.

Jackson, Lucy. 2016. "Intimate Citizenship? Rethinking the Politics and Experience of Citizenship as Emotional in Wales and Singapore." Gender, Place \& Culture, 23(6): 817-833. https://doi.org/10.1080/ 0966369X.2015.1073695.

Jagga, Raakhi. 2021. "Being Labelled Separatist, Khalistani Hurts the Most.” Indian Express, February 13, 2021. https://indianexpress.com/article/cities/chandigarh/being-labelled-separatist-khalistani-hurtsthe-most-7180722/.

Kaur, Mallika. 2020. "Unprecedented Farmers' Protests in India: Lest We Miss This Feminist Moment." Ms. Magazine, December 10, 2020. https://msmagazine.com/2020/12/10/india-farmer-protestfeminist-women/.

Kuchay, Bilal. 2019. "Meet India's Jamia Women who Took on Delhi Police in Viral Video." Al Jazeera, December 17, 2019. www.aljazeera.com/news/2019/12/17/meet-indias-jamia-women-who-tookon-delhi-police-in-viral-video/.

Kumar, Hari and Maria Abi-Habib. 2020. "Muslims Organize Huge Protests Across India, Challenging Modi." New York Times, January 4, 2020. www.nytimes.com/2020/01/04/world/asia/india-protestsmodi-citizenship.html.

Leach, Darcy. 2013. "Prefigurative Politics" in The Wiley-Blackwell Encyclopedia of Social and Political Movements, edited by David A. Snow, Donatella Della Porta, Bert Klandermans, and Doug McAdam. Hoboken, New Jersey: Blackwell Publishing Ltd., pp. 1004-1006.

Mahajan, Anilesh S. 2020. "What Agitating Farmers Want, and Why the Centre may not Oblige." India Today. Retrieved December 6, 2020. www.indiatoday.in/india-today-insight/story/whatagitating-farmers-want-and-why-the-centre-may-not-oblige-1745475-2020-11-30.

Melucci, Alberto. 1996. Challenging Codes: Collective Action in the Information Age. Cambridge: Cambridge University Press.

Menon, Aditya. 2020. "United by Grief: Why Sikhs \& Punjab Farmers are at Shaheen Bagh.” Quint, February 20, 2020. www.thequint.com/news/politics/shaheen-bagh-sikh-farmers-punjab-langarmuslims-caa-nrc-protests.

Menon, Ritu. 2020. "Anti-CAA Protests by Muslim Women are about Where, How and Why You Belong." Indian Express, February 4, 2020. https://indianexpress.com/article/opinion/columns/ shaheen-bagh-anti-caa-protest-mother-india-6249503/.

Mishra, Saksham. 2020. "I am a BJP Supporter but I Oppose the CAA and I'm not Alone.' Arré, January 16, 2020. www.arre.co.in/pov/i-am-a-bjp-supporter-but-i-oppose-the-caa-nrc/ .

Modi, N. @narendramodi.2020, November 29, bow to Sri Guru Nanak Dev Ji on his Parkash Purab. May his thoughts keep motivating us to serve society and ensure a better planet. https://twitter.com/ narendramodi/status/1333244471958355973?lang=en.

NDTV. 2020. "Shaheen Bagh Protesters vs Residents over Road Block." YouTube video, 13:49. January 13, 2020. www.youtube.com/watch? $\mathrm{v}=\mathrm{bPjiH} \_\mathrm{X} 2 \mathrm{unE} \& \mathrm{t}=618 \mathrm{~s}$.

Newsclick. 2021. "Don't Understand Why Children, Old People Kept in Protests." www.newsclick.in/ \%E2\%80\%98Don\%E2\%80\%99t-Understand-Why-Old-People-Women-Kept-in-Protests\%E2\%80\%99CJI\%E2\%80\%99s-Remarks-Spark-Outrage.

Pahwa, Nitish. 2020. "India Just Had the Biggest Protest in World History." Slate, December 9, 2020. https://slate.com/news-and-politics/2020/12/india-farmer-protests-modi.html.

Pandey, Neelam. 2020. "BJP Alleges Khalistani Agenda behind Farmer Protests, Says Congress Playing with Fire." The Print, February 13, 2021. https://theprint.in/politics/bjp-alleges-khalistani-agendabehind-farmer-protests-says-congress-playing-with-fire/553292/Print.

Plummer, Ken. 2003. Intimate Citizenship: Private Decisions and Public Dialogues. Seattle: University of Washington Press.

Prabhu, Maya. 2020. “A Spirit of protest: How Indians are Uniting in Punjab." Al Jazeera, March 19, 2020. www.aljazeera.com/indepth/features/spirit-protest-indians-uniting-punjab-200310053308585.html.

PTI (Press Trust of India). 2020. "Anti-CAA Protest: Gita, Bible and Quran Recited at Shaheen Bagh, in Novel Inter-Faith Meet.” 12 January. The Week. Accessed 24 June 2021. https://www.theweek.in/news/india/ 2020/01/12/anti-caa-protest-gita-bible-quran-recited-shaheen-bagh-in-novel-inter-faith-meet.html. 
Quint. 2019. “'Those Creating Violence can be Identified by their Clothes': PM Narendra Modi on CAA Protests." December 15, 2019. www.thequint.com/news/india/can-be-identifiedby-their-clothes-pm-narendra-modi-on-caa-protesters.

2020a. "Naam Shaheen Bagh Hai: An Ode to Protesters who Sparked a Movement." February 24, 2020. www.thequint.com/news/india/naam-shaheen-bagh-hai-an-ode-to-protesters-who-sparkeda-movement.

_. 2020b. "What Women Farmers Protesting at Singhu and Tikri Borders Want." December 7, 2020. www.thequint.com/news/india/what-women-farmers-protesting-at-singhu-and-tikri-border-want.

Rawat, Gargi and Anindita Sanyal. 2020. "Sikh Farmers from Punjab Come to Cheer Shaheen Bagh Women, Cook Langar." NDTV, January 16, 2020. www.ndtv.com/india-news/sikh-farmers-from-punjabcome-to-cheer-shaheen-bagh-women-cook-langar-2164508.

Said, Atef. 2015. "We Ought to be Here: Historizing Space and Mobilization in Tahrir Square." International Sociology, 30(4): 348-366.

Sainath, P. 2020. "And You Thought It Was Only About Farmers." December 10, 2020. The People's Archive of Rural India. https://ruralindiaonline.org/articles/and-you-thought-its-only-about-farmers/

Sarfaraz, Kainat. 2020. “Transgender, Queer Groups March against CAA, NRC." Hindustan Times, January 4, 2020. www.hindustantimes.com/cities/transgender-queer-groups-march-against-caa-nrc/ story-MU5PFAPVbhdLIUT4Q2y2lO.html.

Sasson-Levy, Orna and Tamar Rapoport. 2003. "Body, Gender, and Knowledge in Protest Movements: The Israeli Case.' Gender and Society, 17(3): 379-403.

Sethi, Chitleen K. 2020. "Five Reasons why Modi Govt. is Finding it Difficult to Tackle Protesting Farmers." The Print, December 8, 2020. https://theprint.in/india/5-reasons-why-modi-govt-isfinding-it-difficult-to-tackle-protesting-farmers/562291/.

Shaheen Bagh Official (@Shaheenbaghoff1). 2020. "The Shaheen Bagh Protest May Have Ended, but Our Movement Lives On.” Twitter, March 24, 2020, 5:55 p.m. https://twitter.com/Shaheenbaghoff1/ status/1242434958523760643.

Shankar, Soumya. 2020. "India's Citizenship Law, in Tandem with National Registry, could make BJP's Discriminatory Targeting of Muslims Easier.' The Intercept, January 30, 2020. https://theintercept.com/ 2020/01/30/india-citizenship-act-caa-nrc-assam/.

Shergill, Sunny. 2020. "Meet the Women Behind the Indian Farmers'Protest." Aljazeera, December 21, 2020. www.aljazeera.com/features/2020/12/21/meet-the-women-behind-the-indian-farmers-protests.

Singh, Pritam. 2020. "BJP's Farming Policies: Deepening Agrobusiness Capitalism and Centralisation." Economic and Political Weekly, 55(41), 14-17.

Singh, Sandeep. 2021. “'We Are One': Why Punjab's Landless Dalits are Standing with Protesting Farmers." The Wire, January 7, 2021. https://thewire.in/caste/punjab-landless-dalit-farmers-protest.

Singh, Sushant. 2019. "The Story of Faiz's Hum Dekhenge — From Pakistan to India, over 40 Years." Indian Express, December 27, 2019. https://indianexpress.com/article/explained/the-story-of-faizshum-dekhenge-from-pakistan-to-india-over-40-years-caa-protest-6186565/.

Week. 2020. "Anti-CAA Protest: Gita, Bible and Quran Recited at Shaheen Bagh, in Novel Inter-faith Meet." January 12, 2020. www.theweek.in/news/india/2020/01/12/anti-caa-protest-gita-biblequran-recited-shaheen-bagh-in-novel-inter-faith-meet.html.

Vishwadeepak. 2020. "Protests against Farm Laws take Anti-Ambani, Anti-Adani Turn in Punjab." National Herald, October 12, 2020. www.nationalheraldindia.com/india/protests-against-farm-laws-takeanti-ambani-anti-adani-turn-in-punjab.

Werbner, Pnina. 1999. "Political Motherhood and the Feminization of Citizenship." In Women, Citizenship and Difference, edited by Nira Yuval Davis and Pnina Werbner. London: Zed Books, pp. 221-245.

Yates, Luke. 2020. "Prefigurative Politics and Social Movement Strategy: The Roles of Prefiguration in the Reproduction, Mobilisation and Coordination of Movements.” Political Studies, 1-20. 